Article

\title{
Impact of Entrepreneurial Orientation on Innovation Capability: The Mediating Role of Absorptive Capability and Organizational Learning Capabilities
}

\author{
Lahcene Makhloufi $^{1, *(\mathbb{D}, \text { Abderrazak Ahmed Laghouag }}{ }^{2}$, Alhussain Ali Sahli ${ }^{2}$ and Fateh Belaid $^{3}$ (D) \\ 1 Department of Technology Management and Logistics, College of Business, University Utara, \\ Sintok 06010, Malaysia \\ 2 Department of Business Administrative, College of Business, King Khalid University, \\ Abha 62552, Saudi Arabia; alaghouag@kku.edu.sa (A.A.L.); alhussainsahli07@gmail.com (A.A.S.) \\ 3 Faculty of Management, Economics \& Sciences, Lille Catholic University, 59000 Lille, France; \\ fateh.belaid@univ-catholille.fr \\ * Correspondence: lahcenma85@gmail.com
}

check for updates

Citation: Makhloufi, L.; Laghouag, A.A.; Ali Sahli, A.; Belaid, F. Impact of Entrepreneurial Orientation on Innovation Capability: The Mediating Role of Absorptive Capability and Organizational Learning Capabilities. Sustainability 2021, 13, 5399. https:// doi.org/10.3390/su13105399

Academic Editors: Olimpia Meglio and Nadia Di Paola

Received: 27 March 2021

Accepted: 29 April 2021

Published: 12 May 2021

Publisher's Note: MDPI stays neutral with regard to jurisdictional claims in published maps and institutional affiliations.

Copyright: (c) 2021 by the authors. Licensee MDPI, Basel, Switzerland. This article is an open access article distributed under the terms and conditions of the Creative Commons Attribution (CC BY) license (https:/ / creativecommons.org/licenses/by/ $4.0 /)$.

\begin{abstract}
Learning and knowledge creation are acknowledged as crucial drivers associated with entrepreneurial orientation (EO) and innovation capability (IC). Absorptive capacity (AC) harmonizes internal innovation-building activities with external opportunities, while organizational learning capabilities (OLC) foster entrepreneurial cognitive skills and innovation capabilities. This study aims to (1) predict the impact of absorptive capacity and organizational learning on IC and (2) to estimate the mediation effect of OLC and AC on the relationship between entrepreneurial orientation and innovation capabilities. Drawing upon the dynamic capability theory, the study had applied a crosssectional survey targeting Algerian firms to test the hypotheses. The study findings indicate that EO is positively associated with innovation capability. Besides, even though both OLC and AC partially increase EO's interaction impact on innovation capability as a mediation role, suggesting that the more a firm is entrepreneurially oriented, the more learning and knowledge creation processes are involved in the interaction relationship. This study's core focus is to overcome the substantial role of learning and knowledge creation processes as an intangible proactive resource that fosters the EO mindset to get involved in innovation activities. It has been discovered that AC and OLC as a connectedness mechanism links external knowledge and internal learning processes to accompany EO readiness during innovation development.
\end{abstract}

Keywords: entrepreneurship orientation; organizational learning capability; innovation capability; absorptive capacity; dynamic capability view

\section{Introduction}

Entrepreneurship orientation is the corporate-level construct seeking to capture and exploit any emerged opportunity proactively [1,2]. Therefore, it is a psychological construct that reflects the intention of top management toward entrepreneurial opportunities in the light of risks and uncertainty [3]. Top-management's EO influences the strategic direction and choices in establishing organizational culture and practices related to the learning process and exploring new opportunities [4,5]. In the era of modernization and globalization, innovation and creative ideas take a pivotal role in business success [6]. Indeed, the strategic decision that encourages firms to begin an entrepreneurial project is an essential driver leading to increasing innovation capabilities $[7,8]$.

The present study aims to extend entrepreneurship research by assuming that dynamic capabilities play a strategic role in converting EO into improved innovation activities. Teece, Pisano [9] thought that dynamic capabilities allow firms to reconfigure existing resources and capabilities. Identifying which capabilities qualify as vibrant to upgrade and reconfigure the entire business process, the strategic management scholars have acknowledged 
that absorptive capacity (AC) is a primary dynamic capability $[5,10]$. AC represents "an ability to recognize the value of new information, assimilate it and apply it to commercial ends" [11]. It is thereby a dynamic capability that associated and helped entrepreneurial activities to handle uncertain situations much more effectively and efficiently by establishing knowledge that is missing relevant to the searched-for opportunity [5]. The study argues that AC facilitates the interaction impact of EO's on innovation activities to overcome the restrictions and explore opportunities [12].

Innovation capability is highly influenced by the extent of entrepreneurial opportunities access and their attitudes to deal with risks and uncertainty [13]. In light of the dynamic capability view, scholars have shown that the relationship between EO and innovation capability is varied and influenced by other intermediate factors [14]. These include organizational and environmental factors. Learning orientation is an inherent power capability [15]. It is a crucial source for developing firms' innovation capability [16] and strengthen EO behavior [17]. The literature has suggested that EO is a behavior that leads firms to proactively act with the emergence of a particular opportunity, innovatively adopt with business changes and deal with high risk and uncertainty to satisfy the desired objectives [18]. In this sense, EO is a strategic mindset of an entrepreneur to spread knowledge and a spirit of sensing and realizing opportunities [19].

Therefore, a firm's EO is able to influence the capability of innovation activities through learning, creation of new ideas, routines and practices, the flow of information, upgrading processes and product design [16]. At the same time, studies such as $[14,20]$ have suggested acquiring knowledge and practices to be leveraged across innovation activities through learning and spirituality of EO is not always applicable. Thus, such mechanisms between these constructs might not be working in certain circumstances such as in developing economies. In a changing business environment, organizational learning capability (OLC) enables firms to up-to-date create new ideas, develop skills and practices [21], which in turn lead to force corporate activities in innovative ways leading to enhance innovation capacities, especially area like new product development, lifecycle and processes [22].

For example, Dess, Ireland [23] viewed organizational learning as two-dimension experimental and acquisition learning. Experimental learning helps firms extend, transform and exploit existing internal knowledge, whereas acquisition learning is considered a firm's competencies to access external knowledge [24]. So far, studies that examined EO and innovation capabilities through the support of OLC are quite rare and suggested for further examination. The study predicts that EO and OLC are associated and complement each other, resulting in more significant opportunities to create valuable knowledge that makes them the leading markets. Due to the lack of studies that examined the link between EO and OLC especially in the context of developing countries like Algeria, thus, we assume that $\mathrm{EO}$ will increase the learning orientation to continuously enhance activities that are based on innovation.

In doing so, this study contributes to the literature from three perspectives. First, this study emphasizes how the EO and OLC influence the IC of large and medium firms in the Algerian context. Most past studies [15,19,25,26] introduced several models, and theories to predict innovation performance and its associated outcomes were ignoring other factors like learning orientation or adopted knowledge. Therefore, examining EO's interrelationships as a strategic asset and OLC as an internal enabler driver of knowledge may inspire entrepreneurs' attitudes. Second, emphasizing learning mechanisms as a link between EO and IC, the study results will contribute to the body of entrepreneurship literature by providing evidence about these interrelationships and how they complement each other to increase innovation activities. The results will accommodate managers on creating valuable resources such as knowledge, skills, practices and know-how through the leveraging of learning orientation. Third, in choosing Algeria as the context of this study, results will strengthen the literature beyond those conducted in developed countries where EO and OLC are varied and primarily different due to the differences in terms of the psychological side of entrepreneurs, firms resources, economic facilities and markets [19,27]. 
This study's empirical evidence will also offer crucial managerial guidance to firms in other transitional contexts trying to enter the global market economy.

In order to empirically validate the theoretical assumptions. The study analyses the close interaction that occurred when firms are entrepreneurially oriented to improve innovation-building activities. Drawing upon DCT, the study developed a theoretical model to link EO with AC, arguing it as a major dynamic capability required to enhance innovation capabilities. In doing so, the study emphasizes Miller's [28] call to develop theories of related disciplines such as entrepreneurship and strategic management to promote which resources and capabilities support entrepreneurial processes.

Researchers have conceptually expected that dynamic capabilities are the "key for linking EO to opportunities exploitation and their subsequent outcomes" [29], which still required further investigation. Furthermore, following Barreto [30], claims that it must be determined whether dynamic capabilities like $\mathrm{AC}^{\prime}$ directly lead to performance outcomes and the boundary conditions must be understood. However, while the majority of past studies (such as Engelen, Kube [5]) examine different performance measures related to EO-AC, the literature shows a lack of studies that focused on how $\mathrm{AC}$ is associated with EO in improving innovation capabilities. Thus, the study concludes with a new model that aims to extend EO research and elaborate these critical gaps by empirically testing the hypotheses.

This study is arranged in the following sections-first, the authors begin by introducing and discussing the theoretical background. Secondly, the paper discusses the detailed hypotheses development. In the third section, the article addresses the research methodology, while the fourth section emphasizes data analysis. The last section includes the discussion of the finding, conclusion and the limitations of the study.

\section{Theoretical Background and Hypotheses Development}

Entrepreneurship orientation (EO) has emerged as a primary construct within entrepreneurship and strategic literature [29,31]. Miller and Friesen [32] introduced the characteristics of entrepreneurially oriented firms in three well-known dimensions, namely (1) be innovative to explore new opportunities, (2) be proactive to market entry before rivals, and (3) be risk-taking to introduce new products. The resource-based view (RBV) advocates that internal resources and capabilities act as key determinants of EO. However, RBV researchers have acknowledged certain shortcomings of the theory, which probably tends to be the case for many entrepreneurially oriented corporations [33]. Therefore, the DCT was applied to extend the RBV lens and answer the question concerning what kind of resources might be meaningful when the environment is continuously uncertain [30]. From the DCT lens, these existing resources were reconfigured, constituting dynamic capabilities. A lack of studies has been observed on examining the association link between dynamic capabilities and EO. An ongoing debate in the DCT research field is whether organizational skills can be dynamic capabilities [5]. Several strategic researchers have agreed on the importance of absorptive capacity (AC) as a dynamic capability $[5,10]$. AC is defined as "an ability to recognize the value of new information, assimilate it, and apply it to commercial ends" [11], based upon the existing knowledge in the firm.

$\mathrm{AC}$ is the core example of dynamic capability embedded within firms' routines and culture, leading to combining capabilities in a novel way to complement each other. It is "the firm's ability to create and deploy the knowledge necessary to build other organizational capabilities (e.g., marketing, distribution, and production)" [10]. Zahra and George [10] introduced four dimensions that constitute AC-acquisition, assimilation, transformation and exploitation, as the main comprehensive pillars that cover the overall activities identified in AC definition. Acquisition refers to the activities associated with external sources of knowledge such as suppliers, consultants, competitors, public networks and trade fairs [34]. Assimilation is the process capability to interpret, analyze and understand externally acquired knowledge [5]. Simultaneously, transformation emphasized the improvements in routines that promote existing learning with acquired and assimilated ones to develop new knowledge [10,35]. Finally, exploitation is the use and leverage of the 
established expertise for commercial ends [11,36]. Therefore, AC constitutes two sides that interact and complement each other. Knowledge access sources (e.g., information, data, and reports) are externally dealt with and are internally recombined and these pieces of new knowledge are applied with existing ones to develop new products, new techniques, processes, routines and practices $[11,37]$.

A considerable number of studies have agreed with the notion that $\mathrm{AC}$ has a direct impact on improving innovation activities [38-40]. Nevertheless, Lee, Leong [41] empirically examined, and found a non-significant effect of, knowledge acquisition on technological innovation. According to Aljanabi [40], AC can facilitate technological innovation and estimate the value created by determining the rapidity and frequency of innovation activities. Within this context, prior studies $[42,43]$ suggested that innovation capabilities highly depend on the capacity of an organization to create new skills and practices facilitated by the integration of external knowledge with the internal knowledge base. Hung, Lien [44] suggested that firms seek to achieve a high level of innovation capabilities through facilitating knowledge integration between individuals and groups. Hence, building absorptive capacity and leveraging new knowledge is a prerequisite for accessing external sources' innovation [40]. AC becomes a crucial capability to ensure continuous innovation through building internal capabilities and reconfiguring competencies to deal with market uncertainty. Consequently, well-established AC leads to an increase in the capacity of knowledge generation and innovation capability performance [45]. A recent empirical study by Aljanabi [40] emphasized the direct and indirect impact of AC on technological innovation, and the results show that $\mathrm{AC}$ directly impacts product and process innovation.

To conclude, AC is embedded within all innovation activities stages, especially at product development phases [46]. Therefore, $\mathrm{AC}$ is the process of acquiring new knowledge that is needed for commercial ends, responding to the changes that occurred among different business environment partners.

Lumpkin and Dess [47] argued that entrepreneurially oriented firms are much more able to succeed than non-entrepreneurially oriented firms due to their capabilities to pursue market opportunities continuously. AC is the central capability that gave entrepreneurially oriented firms the key to access new information and knowledge about these opportunities through several channels [37]. The acquired new information is the core focus of $\mathrm{AC}$ to generate new ones [5]. In counterpart, EO firms with poor AC usually struggle to explore new opportunities due to a lack of knowledge access and evaluation and due to inappropriately dealing with existing knowledge [5], which inhibits the relationship between EO and innovation capabilities. Furthermore, high AC increases innovation activities and speed, developing new products and services responding to market opportunities [48].

Researchers have suggested two approaches to dealing with AC and EO. The first approach explored AC as a determinant of EO. Zahra, Filatotchev [49], for example, viewed AC as the critical determinant that improves the capacity to explore and exploit new opportunities. In contrast, the second approach introduced AC as a moderating role in the EO-firm performance relationship. Particularly, Hayton and Zahra [50] examined the impact of $A C^{\prime}$ 's moderating role between external venturing activities and firm performance (e.g., revenue growth and new product development). Moreover, Zahra and Hayton [51] and Engelen, Kube [5] used AC as a moderating role to estimate EO's impact on different performance measures. Recent empirical findings by Zhai, Sun [48] indicate that AC strengthens EO's technological innovation effect. Besides, studies such as Wales, Gupta [52] found that EO improves financial returns at lower AC levels and reduces the performance decline at a high AC level. The study also demonstrated that a higher level of EO accompanied by a higher lever AC resulted in different performance measures [52].

However, estimating higher $\mathrm{EO}$ outcomes and consequences that accompanied higher $\mathrm{AC}$ on innovation capabilities is an important theoretical and practical gap. Examining the mediating role of $\mathrm{AC}$ on the relationship between $\mathrm{EO}$ and innovation capabilities is overlooked in the literature. Following Aljanabi's [40] study, which examined the mediating role of AC on the relationship between $\mathrm{EO}$ and technological innovation, this study tests and extends 
the theory in another context. The lack of studies motivates us to conduct this research by proposing AC as having a mediating role in the EO-IC relationship. In addition, the literature still struggles to provide a clear image of and evidence about how EO complements $\mathrm{AC}$ and how they interact with each other, especially during the AC knowledge creation processes and then to what extent that $\mathrm{AC}$ is able to influence $\mathrm{EO}$ activities. Proactiveness and innovativeness, which constitute EO, rely on the success of $\mathrm{AC}^{\prime}$ 's knowledge creation processes. A review of past studies by Kube [5] found that the relationship between EO, IC, and absorptive capacity was poorly addressed. This critical gap should be examined by introducing $\mathrm{AC}$ as a mediator between $\mathrm{EO}$ and innovation capability.

This paper aims to understand how the four AC dimensions interact with EO (e.g., innovativeness, proactiveness and risk-taking) as a mechanism for leveraging new practices and skills to enhance innovation capabilities. Referring to Zahra and George [10] and Covin and Slevin [33], the study extends the EO and AC models and intends to test the following proposed hypotheses:

Hypothesis 1. EO is positively associated with absorptive capacity.

Hypothesis 2. Absorptive capacity positively influences innovation capability.

Hypothesis 3. Absorptive capacity mediates the relationship between EO and innovation capability.

The entrepreneurship literature has shown that those firms that are entrepreneurially oriented are characterized by innovativeness to introduce new products, proactiveness to the market, and risk-taking to explore new opportunities [52], enabling them to fit customers' and market's requirements through innovation [53,54]. A shred of empirical evidence has suggested that EO is one of the pivotal resources embedded with significant power over the adaptability to business changes consisting of paths to success in innovative ways [55].

Innovation in novel ways leads to the creation of new ideas and development of actual practices that overcome the risk-taking associated with proactive strategies to extend business growth [13]. Previous studies [4,56] have defined and measured EO by different dimensions depending on the research and the theoretical base's context. However, Miller's three dimensions that measure EO were proposed in 1987-innovativeness, risk-taking, and proactiveness [4]. These dimensions were mainly tested by massive studies that validated the EO construct concept [1]. Innovativeness refers to creating new ideas, developing skills, leveraging new techniques and upgrading product design and processes [57]. In doing so, innovation in novel ways allows firms to generate new knowledge and transform it across the organizational hierarchy. This leads to developing new products and enhancing the innovation performance of different activities [7].

Proactiveness refers to the attitudes of entrepreneurs to taking actions in advance to be the leading market strategy by introducing new products, using new processes and technologies, and to being the pioneer in responding to customer needs, which leads to transcending rivals [57]. Firms that proactively respond to the market demands, customer needs, and competitors' actions can always take advantage of the market opportunities by first introducing their products and services [15]. Therefore, a proactive strategy plays a vital role in accessing business opportunities before rivals, exploiting and making it difficult for a competitor to understand them [58]. The third dimension is risk-taking, which means the investment risk to generate high economic reward is usually influenced by the attitudes and mindsets of entrepreneurs to yield great wealth [56]. This behavior can be explained from two points of view, namely technology and the market.

From the technological side, risk-taking means the extent to which firms are ready to invest in technological innovation or projects expecting high reward accompanied by increased risk and uncertainty, which depend on the mindset of the entrepreneur and their attitudes [58]. The entrepreneur believes investing in new technology would improve innovation capability and business performance considering all circumstances that might occur [59]. Risk-taking encourages firms to experiment and move from a stable environment to a high uncertainty 
environment by learning, acquiring, and absorbing new ideas, opportunities and knowhow to ultimately predict economic benefits [60]. From a market perspective, it reflects an organization's willingness to challenge the uncertainty risk of handling new markets and customers [59]. Under this tendency, firms usually act in advance to predict the market's future scenarios and then seek, explore and sense newly emerged opportunities to have a first-mover advantage, thereby resulting in huge benefits [40].

Some researchers $[15,59,61]$ believe that entrepreneur attitude could directly influence the innovation activities of products, processes and management, and they proposed innovation as an indicator of EO in their studies. EO can improve the firm's proactiveness decisions, transfer risk-taking uncertainty into opportunities, and innovatively apply new ideas and practices [1,62]. At the same time, these three main pillars of EO are addressed to maximize the benefits of innovation capabilities and to continuously improve the core competitiveness of an organization. Thus, we hypothesize:

\section{Hypothesis 4. Entrepreneurship orientation positively influences innovation capability.}

An inspired entrepreneur's primary purpose is to explore and exploit business opportunities. This inspiration can occur once entrepreneurs continuously learn how to search, recognize and absorb potential valuable knowledge [15]. Organizational learning is acknowledged as an essential strategic factor that facilitates knowledge acquisition and utilization [56]. Studies observed that a high-level entrepreneurial mindset is always looking for learning and knowledge as a vital competitive advantage source. Notably, these studies by Keh, Nguyen [63] and Sapienza, De Clercq [64] confirmed that entrepreneurs' proactive strategies acquired, utilized and shared knowledge more intensively.

Another empirical study by Wang [60] found that learning commitment mediated the relationship between EO and UK firm's performances. Firms that strategically proactive and innovatively manage their business operation usually possess a strong culture of learning and sharing information, which helped those firms yield and develop actual knowledge to capture opportunities faster than their competitors [15]. Therefore, OL enables entrepreneurs to own a strategic mindset to create wealth and build their dynamic capabilities [12]. EO engages in high learning orientation, which is the primary source of knowledge and quick adaptation in a fast-paced business environment.

Besides, engaging in organizational learning can help firms control high uncertainty by providing a clear image and information about the entire business situation and its relevant opportunities or threats, allowing firms to quickly decide, adopt and gain advantages [65]. In transitional economies, such as in the Algerian context, entrepreneurs are highly recommended to learn and acquire knowledge before deciding any strategic decision since they suffer from fewer resources and less capital [16]. Therefore, this study predicts that EO will engage in learning activities to create new knowledge and develop entire business processes, including innovation activities [60]. To take advantage of entrepreneurial opportunities, learning activities are the fundamental key to combining actual knowledge, practices, skills and know-how with newly developed ideas in a single unique organ, which reflect the reliable organizational learning capabilities that, in turn, take risks to invest and capture opportunities [16].

Organizational learning is how organizational factors interact and complement each other, such as routines, know-how, ideas and skills, which lead to formulating a special unique learning process that results in different outcomes at managerial, operational, and functional levels [16]. This could be the primary source of innovation [16]. OLC is the critical source of creative ideas, practices and skills that foster employee performance and management capabilities to innovatively increase business performance across the learning process [65]. Past studies have highlighted that OL acquires the possibility of improving innovation capabilities [15]. Learning is an essential factor that fosters managerial, product and process capacities to understand the business changes and respond to market demands [16]. This can occur once these factors are innovatively integrated. 
Learning orientation is one of the leading guides that provides a straightforward platform for future business operations by distinguishing tasks, determining procedures, and the firms' final vision for the future [65]. OL helps top management observe, explore and develop management tasks' weakness and employees' skills and encourages them to innovate in novel ways. OLC can be seen from developing new products and designs because of its activities involved in the learning processes [66]. A study by Hult, Hurley [67] pointed out that OLC is the learning that brings new ideas, creating valuable knowledge concerning products, processes and know-how, which are highly associated with innovation outcomes. Empirical findings by Alegre and Chiva [15] revealed that OLC directly impacts innovation capabilities and encourages EO to enhance innovation activities. Jiménez-Jiménez and Sanz-Valle [65] empirically tested the impact of OL on both innovation and firm performance. The study found that OL positively influences innovation capability, which increases the performance of firms.

Learning capabilities can be viewed as organizational creativity that seems to be a complementary asset to entrepreneurs [14]. OL refers to the learning process of how and why we need to conduct the business? It creates new ideas and upgrades business processes [14], aiming to leverage the culture of learning and collaboration among all organizational partners, which leads to the generation of valuable knowledge from different sources [68], therefore is extremely supportive of innovation activities via novel ideas and skills. Authors Lakhani, Lifshitz-Assaf [69] stated that open innovation is a vital motivator source for firms willing to learn and exceed uncertainty. Studies have suggested that OL influences firm performance $[15,16,70]$. Learning processes enable new product development $[71,72]$ and facilitate new projects [73,74] and the upgrading of processes [27]. This led to innovation in novel ways and thus enhances both business and innovation performance.

An empirical study by Keskin [75] found that organizational learning orientation positively impacts innovativeness and mediates the relationship between market orientation and innovativeness. A recent empirical study by Shaher and Ali [76] revealed and emphasizes a positive direct impact of $\mathrm{EO}$ on organizational learning orientation and innovation performance (e.g., product, processes, and marketing innovation). The study also found a positive mediation impact of OL between EO and innovation performance [76]. OLC plays an essential role in fostering EO to capture opportunities and in understanding business trends [77]. This can happen when OLC provides reliable platforms to leverage creative ideas, know-how, upgrade employees' skills and practices, reconfigure business processes, and improve entrepreneurs competencies, which probably leads to improvement of EO innovativeness.

Furthermore, the learning process capacity focuses on upgrading and leveraging new practices, especially at functional levels [78], allowing firms to have first-mover advantages by presenting new products and services before rivals. Thus, it reflects that OLC somewhat empowers EO proactiveness to introduce and explore new products and markets. Additionally, following the dynamic capability lens, the learning process capability is an enabling source of a firm's dynamic capacity to deal with high risk business projects [79]. The more a firm acquires solid dynamic capabilities, the more it intentionally searches for challenging, high-risk investments to maximize high return [77].

This association between OLC and EO reflects the close interaction of these capabilities to complement each other. An empirical study [77] emphasizes the interface between OLC, $\mathrm{EO}$, and small business performance. The study used EO and OLC interchangeably as a mediator to predict the business performance of small firms. The findings indicated that OLC does not mediate the EO-business performance relationship while EO does mediate the relationship [77]. The study argued that firms could develop EO by increasing investment in the resources needed to improve learning process capability [77]. Therefore, firms should adopt and develop effective learning mechanisms that might lead to stimulation of EO activities. Thus, EO is highly impacted by the extent to which learning orientation is developed and leveraged across firms' boundaries. However, it is not clear how learning capability stimulates EO activities to build innovation capability as a critical solution, which is overlooked in the entrepreneurship and innovation management literature. Hence, this 
study assumes that OLC increases EO (e.g., innovativeness, proactiveness, and risk-taking) impact on innovation capabilities. Thus, these lines of arguments lead us to the following hypotheses:

Hypothesis 5. Entrepreneurship orientation is positively associated with organizational learning capability.

Hypothesis 6. Organizational learning capability positively influences innovation capability.

Hypothesis 7. Organizational learning capability mediates the relationship between entrepreneurship orientation and innovation capability.

Following the above hypotheses, this study investigates the relationship between entrepreneurship orientation, absorptive capacity, organizational learning, and innovation capability (Figure 1).

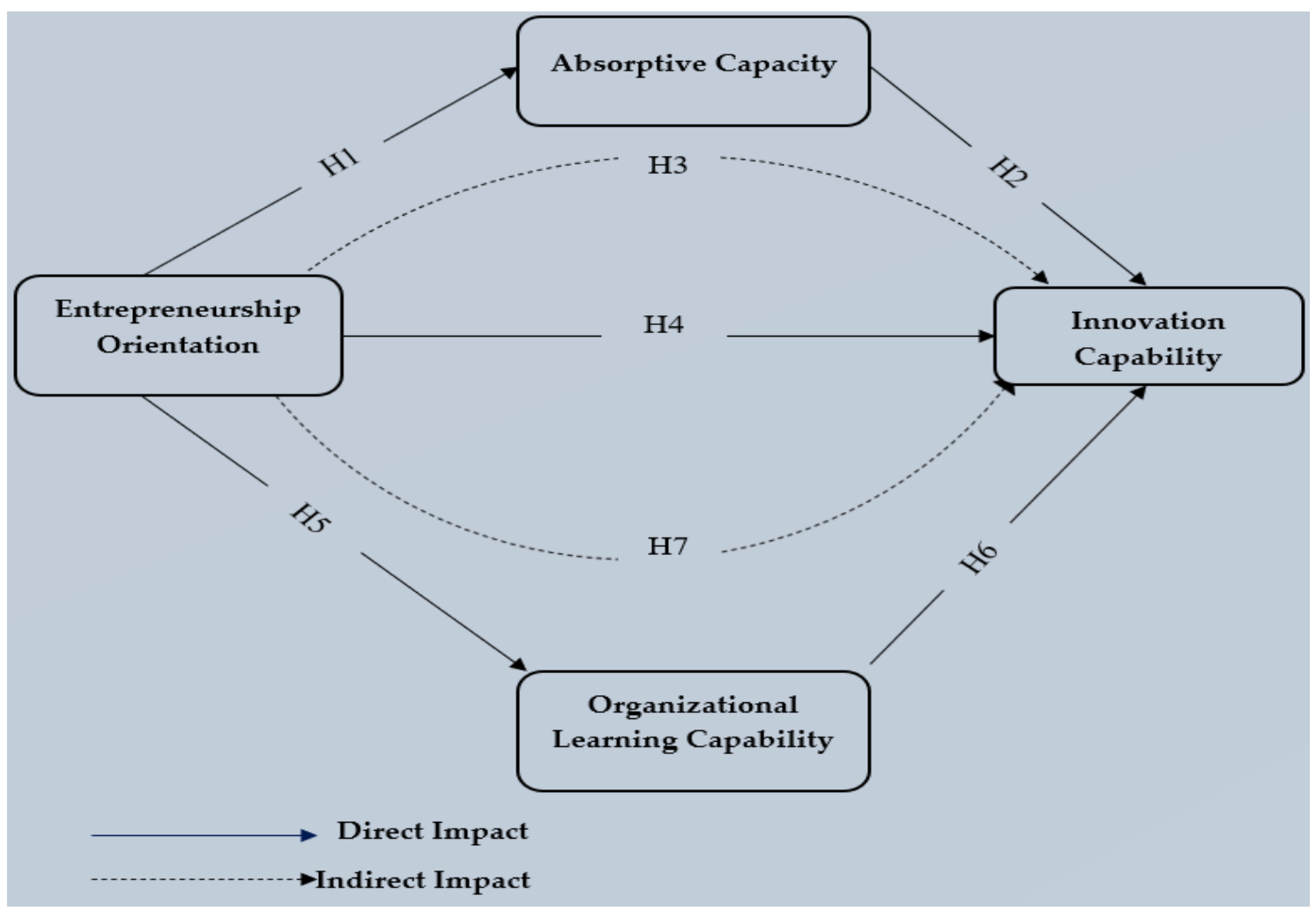

Figure 1. Theoretical Framework.

\section{Research Methods}

\subsection{Sampling Technique and Data Collection}

This research intends to address the effects of entrepreneurship orientation on a firm's innovation capabilities. The theoretical model, presented in (Figure.1), illustrates the interrelationships between the framework constructs, taking into account the proposed hypotheses above in the literature review. Selecting the appropriate respondents is an important step for accessing accurate data to test the specific relationships between all the corresponding variables of the research model.

This study targets top managers and entrepreneurs to conduct an empirical investigation focuses on medium and large firms. The study's scope covers six major large industrial zones in Algeria: Alger, Setif, Bejaia, Oran, Constantine, and Boumerdes. The population of the study was 9451 firms registered in KOMPASS (https: / / dz.kompass.com, accessed on 25 March 2021). 
Applying the random sampling technique, the study sample size was 370 [80]. However, due to the low response rate and missing survey issues, to overcome this problem, researchers such as Kotrlik and Higgins [81] recommended adding 40\% to the sample size. The author sends 500 questionnaires (in a dual language, along with a cover letter explaining the importance of the study and its main ethical/scientific goals); only 194 completed surveys were gathered with complete data, representing a response rate of $37.4 \%$.

This research conducts a pilot study to ensure the validity and content quality of the items. Therefore, the authors invited two academic experts in entrepreneurship studies and three professional managers working in the electronic firms' industry. Following the academic experts' comments and the feedback of managers, the questionnaire's final draft was then made. After that, 14 managers operating in electronic firms were also asked to participate in a pilot study. The obtained results indicated an adequate internal consistency and acceptable composite reliability of all the constructs, ranging from 0.763 to 0.848 . The final version of the survey was established before being distributed to the respondents. The constructs were measured using a seven-point Likert-type scale, ranging from " 1 " representing "strongly disagree" to "7" representing "strongly agree." Table 1 below represent firms and respondent's demographic data.

Table 1. Background of respondents and firms.

\begin{tabular}{ccc}
\hline Respondent's Profile & Frequency & Percentage (\%) \\
\hline Industry type & & \\
Electrical and electronic & 53 & 27.3 \\
Chemistry and plastic & 26 & 13.4 \\
Agri-food & 31 & 15.9 \\
Food and mineral industry & 42 & 21.6 \\
Construction and habitat & 18 & 9.2 \\
Energy and environment & 24 & 12.3 \\
Education & 37 & 19.1 \\
Diploma & 92 & 47.4 \\
Undergraduate & 65 & 33.5 \\
Postgraduate & & \\
Years of experience & 62 & 31.9 \\
1 to 5 years & 74 & 38.2 \\
5 to 10 years & 58 & 29.8 \\
More than 10 years & & \\
Firm's age & 29 & 14.9 \\
1-5 years & 55 & 28.4 \\
6-10years & 72 & 37.1 \\
10 -15 years & 38 & 19.6 \\
More than 15 & & \\
Position & 94 & 48.4 \\
Manager & 78 & 40.2 \\
Chief executive officer & 22 & 11.3 \\
General manager & & 17.5 \\
Number of employees & 34 & 29.4 \\
Between 50 to 100 & 57 & 38.2 \\
100 to 250 & 74 & 14.9 \\
251 to 500 & 29 & \\
More than 500 & & \\
\hline & & \\
\hline
\end{tabular}

\subsection{Measurement of Variables}

The measurement tool applied to estimate variables of this study was adapted from past studies to the Algerian industry context to fit the study's objective. Entrepreneurship orientation was measured using three well-known dimensions, namely innovativeness, proactiveness and risk-taking. adopted from [33] and [15]. Innovation capability was measured by using five items adopted from Ferreira, Coelho [13]. Organizational learning capability was estimated by using five items adopted from [14]. Absorptive capacity is 
composed of four dimensions; acquisition and assimilation measured by four items, while three items estimated transformation and exploitation. ACAP was based on studies carried out by $[10,11,26]$.

\section{Data Analysis}

The study uses the Partial Least Square Structural Equation Modeling (PLS-SEM) to predict and assess the measurement and structural models [82]. The study is aware of nonresponse bias. Thus, an independent samples t-test was performed to detect any possibility of non-response bias (the differences between early and late respondents who might share the same characteristics). The study found that Levene's test for equality of variance was higher than the 0.05 of all constructs that fulfilled the significance level requirement based on [83], suggesting that this study is free of non-response bias. To ensure the validity of the overall relationships in the model, examining if there are any measurement errors is important, through checking whether it is free of common method variance (CMV) by applying a full collinearity test. The estimated observed values of variance inflation factors (VIFs) generated for all factors must be below 3.3 [84]; the results indicated that the model was free of CMV.

\subsection{Validity and Reliability Assessment}

The study applied PLS-SEM to test convergent validity and discriminant validity of the measurement tool. Convergent validity was tested by checking the indicator's outer loading, factor loading, composite reliability, and average variance extracted (AVE). As shown in Table 2, all item loadings were higher than 0.70 [85]. Likewise, all constructs composite reliability was higher than 0.70 [86], while AVE values were bigger than 0.50, as suggested by [87].

The study tested the discriminant validity through the Fornell and Larcker Criterion to examine the comparison of correlation between endogenous variables with the square root of the AVE of the constructs itself. As shown in Table 3, the diagonals' bolded values were higher than the values in their respective row and column, thus indicating that the measures used in this study were discriminant. The cross-loading criterion was also tested and results stated that outer loading exceeded cross-loading for all constructs, and the results remained valid. Additionally, the Heterotrait-Monotrait (HTMT) ratio developed by Henseler, Ringle [82] was also examined to further check that the model is well-examined. The values presented in parentheses in Table 3. are less than 0.85 and thus met the criterion of $\mathrm{HTMT}_{.85}$ [88], indicating that discriminant validity was achieved. The confidence interval does not show a value of 1 on any of the variables [82], which means discriminant validity is confirmed.

Table 2. Convergent outcomes of the study.

\begin{tabular}{|c|c|c|c|c|c|c|}
\hline \multicolumn{7}{|c|}{ Constructs } \\
\hline 1st Order & 2nd Order & Items & Loadings & CA & CR & AVE \\
\hline \multirow{4}{*}{ Acquisition } & & ACQ 1 & 0.889 & \multirow{4}{*}{0.920} & \multirow{4}{*}{0.944} & \multirow{4}{*}{0.807} \\
\hline & & ACQ 2 & 0.866 & & & \\
\hline & & $\mathrm{ACQ} 3$ & 0.931 & & & \\
\hline & & ACQ 4 & 0.906 & & & \\
\hline \multirow{4}{*}{ Assimilation } & & AS 1 & 0.886 & \multirow{4}{*}{0.926} & \multirow{4}{*}{0.948} & \multirow{4}{*}{0.819} \\
\hline & & AS 2 & 0.890 & & & \\
\hline & & AS 3 & 0.935 & & & \\
\hline & & AS 4 & 0.908 & & & \\
\hline
\end{tabular}


Table 2. Conts.

\begin{tabular}{|c|c|c|c|c|c|}
\hline \multicolumn{6}{|c|}{ Constructs } \\
\hline 2nd Order & Items & Loadings & CA & CR & AVE \\
\hline \multirow{4}{*}{ Exploitation } & EX 1 & 0.913 & \multirow{4}{*}{0.814} & \multirow{4}{*}{0.890} & \multirow{4}{*}{0.732} \\
\hline & EX 2 & 0.887 & & & \\
\hline & EX 3 & 0.757 & & & \\
\hline & TR 1 & 0.920 & & & \\
\hline \multirow{3}{*}{ Transformation } & TR 2 & 0.919 & \multirow[t]{3}{*}{0.912} & \multirow{3}{*}{0.944} & \multirow{3}{*}{0.850} \\
\hline & TR 3 & 0.926 & & & \\
\hline & Acquisition & 0.573 & & & \\
\hline \multirow{4}{*}{ Absorptive Capacity } & Assimilation & 0.813 & \multirow{4}{*}{0.909} & \multirow{4}{*}{0.922} & \multirow{4}{*}{0.465} \\
\hline & Exploitation & 0.821 & & & \\
\hline & Transformation & 0.844 & & & \\
\hline & INN 1 & 0.853 & & & \\
\hline \multirow[t]{3}{*}{ Innovation } & INN 2 & 0.841 & \multirow[t]{3}{*}{0.724} & \multirow[t]{3}{*}{0.846} & \multirow[t]{3}{*}{0.648} \\
\hline & INN 3 & 0.712 & & & \\
\hline & PR 1 & 0.916 & & & \\
\hline \multirow[t]{3}{*}{ Proactiveness } & PR 2 & 0.940 & \multirow[t]{3}{*}{0.921} & \multirow[t]{3}{*}{0.950} & \multirow[t]{3}{*}{0.863} \\
\hline & PR 3 & 0.930 & & & \\
\hline & RT 1 & 0.927 & & & \\
\hline \multirow[t]{3}{*}{ Risk-Taking } & RT 2 & 0.873 & \multirow[t]{3}{*}{0.894} & \multirow[t]{3}{*}{0.934} & \multirow[t]{3}{*}{0.825} \\
\hline & RT 3 & 0.924 & & & \\
\hline & Innovativeness & 0.795 & & & \\
\hline \multirow[t]{4}{*}{ Entrepreneurship Orientation } & Proactiveness & 0.929 & \multirow[t]{4}{*}{0.913} & \multirow[t]{4}{*}{0.930} & \multirow[t]{4}{*}{0.580} \\
\hline & Risk-Taking & 0.929 & & & \\
\hline & OLC 1 & 0.887 & & & \\
\hline & OLC 2 & 0.928 & & & \\
\hline Organizational Learning Capability & OLC 3 & 0.912 & 0.941 & 0.955 & 0.808 \\
\hline & OLC 4 & 0.911 & & & \\
\hline & OLC 5 & 0.856 & & & \\
\hline & IC 1 & 0.900 & & & \\
\hline & IC 2 & 0.908 & & & \\
\hline Innovation Capability & IC 3 & 0.897 & 0.942 & 0.956 & 0.811 \\
\hline & IC 4 & 0.886 & & & \\
\hline & IC 5 & 0.912 & & & \\
\hline
\end{tabular}

Table 3. Farnell and Locker Criterion and HTMT ratio.

\begin{tabular}{cccccccccc}
\hline & ACQ & AS & EX & TR & INN & RT & PR & OLC & IC \\
\hline ACQ & $\mathbf{0 . 8 4 3}$ & & & & & & & & \\
AS & 0.621 & & & & & & & & \\
& $(0.802)$ & $\mathbf{0 . 7 8 2}$ & & & & & & & \\
EX & 0.534 & 0.652 & $\mathbf{0 . 7 7 4}$ & & & & & & \\
& $(0.746)$ & $(0.573)$ & & & & & & & \\
TR & 0.567 & 0.238 & 0.492 & & & & & \\
& $(0.413)$ & $(0.434)$ & $(0.824)$ & $\mathbf{0 . 8 1 6}$ & & & & \\
INN & 0.463 & 0.628 & 0.563 & 0.634 & & & & \\
& $(0.458)$ & $(0.683)$ & $(0.814)$ & $(0.483)$ & $\mathbf{0 . 8 4 1}$ & & & \\
RT & 0.683 & 0.649 & 0.724 & 0.546 & 0.392 & & & \\
& $(0.745)$ & $(0.784)$ & $(0.704)$ & $(0.582)$ & $(0.673)$ & $\mathbf{0 . 7 6 9}$ & & & \\
PR & 0.325 & 0.424 & 0.246 & 0.458 & 0.524 & 0.436 & $\mathbf{0 . 8 3 4}$ & & \\
& $(0.679)$ & $(0.267)$ & $(0.487)$ & $(0.626)$ & $(0.348)$ & $(0.478)$ & & \\
OLC & 0.472 & 0.452 & 0.562 & 0.602 & 0.547 & 0.236 & 0.621 & $\mathbf{0 . 8 6 2}$ & \\
& $(0.378)$ & $(0.374)$ & $(0.469)$ & $(0.487)$ & $(0.568)$ & $(0.526)$ & $(0.478)$ & \\
IC & 0.428 & 0.364 & 0.724 & 0.283 & 0.234 & 0.461 & 0.082 & 0.284 & $\mathbf{0 . 8 4 7}$ \\
& $(0.478)$ & $(0.573)$ & $(0.758)$ & $(0.236)$ & $(0.682)$ & $(0.734)$ & $(0.308)$ & $(0.624)$ & \\
\hline
\end{tabular}




\subsection{Structural Model Analysis}

The structural path in Figure 2 and tabulated results in Table 4. showed a positive and significant relationship between EO and ACAP $(\beta 1=0.491, t=12.717, p<0.001)$, indicating that $\mathrm{H} 1$ is supported. Furthermore, the results showed that ACAP positively and significantly influenced IC ( $\beta 4=0.562, \mathrm{t}=11.12, p<0.001)$, signifying that $\mathrm{H} 2$ was supported. Moreover, EO has a positive and significant effect on IC ( $\beta 3=0.191, t=4.27$, $p<0.001$ ), denoting that $\mathrm{H} 4$ is maintained. Next, the EO path was positive and statistically significant on OLC ( $\beta 2=0.391, \mathrm{t}=6.65, p<0.001)$, inferring that the hypothesis H5 is retained. Besides, OLC has a significant and positive effect on IC $(\beta 5=0.180, t=2.75$, $p<0.001)$, which means H6 is supported.

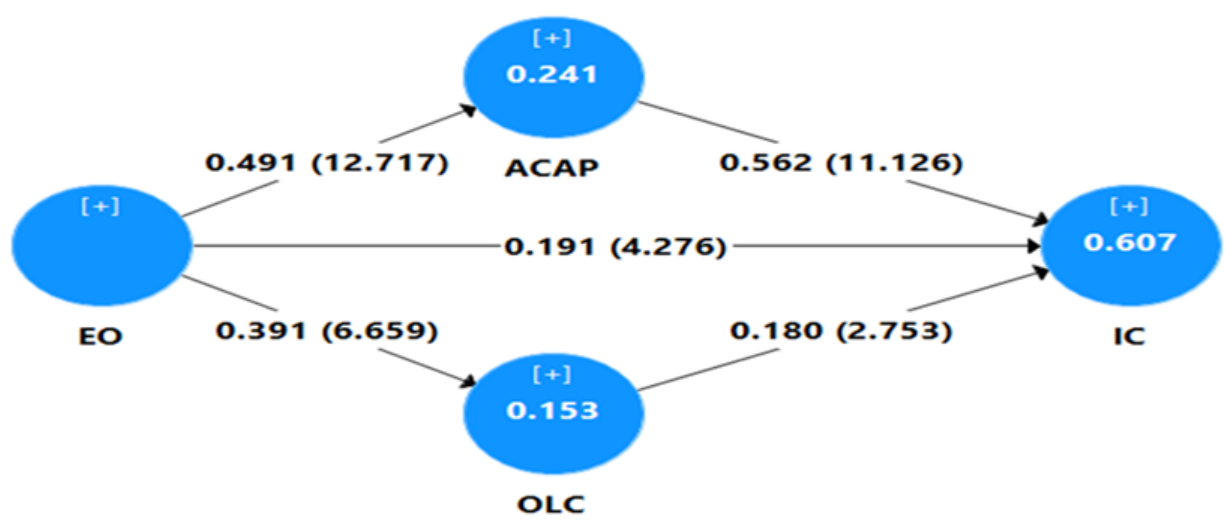

Figure 2. Structural Model. EO: entrepreneurship orientation; ACAP: absorptive capacity; OLC: organizational learning capability; IC: innovation capability.

Table 4. Structural model results.

\begin{tabular}{cccccccc}
\hline $\mathbf{H}$ & Relationship & Beta & $\boldsymbol{t}$-Value & $\boldsymbol{p}$-Value & $\boldsymbol{R}^{\mathbf{2}}$ & $\boldsymbol{f}^{\mathbf{2}}$ & Decision \\
\hline H1 & EO -> ACAP & 0.491 & 12.717 & $0.000^{*}$ & 0.241 & 0.317 & Supported \\
H2 & ACAP -> IC & 0.562 & 11.126 & $0.000^{*}$ & & 0.55 & Supported \\
H4 & EO -> IC & 0.191 & 4.276 & $0.000^{*}$ & 0.607 & 0.087 & Supported \\
H5 & EO -> OLC & 0.391 & 6.659 & $0.000^{*}$ & & 0.18 & Supported \\
H6 & OLC -> IC & 0.180 & 2.753 & $0.003 *$ & 0.153 & 0.093 & Supported \\
\hline Note: ${ }^{*} p 0.001$ (1 tailed). & & & & & &
\end{tabular}

\subsection{The Effect Size}

The effect size $\left(f^{2}\right)$ of endogenous variables on a particular exogenous one explains to what extent these variables are connected and influence the dependent variable, simultaneously showing the model's strength [85]. In the empirical study, variables might possess $f^{2}$ values of $0.02,0.15$, and 0.35 , which are considered small, medium, and large effect sizes, respectively [89]. As tabulated in Table 4, EO's effect size on both ACAP and OLC was medium, whereas EO and OLC's effect on IC was small. The study shows that ACAP has a large effect size on the IC. Besides, the variance explained by indigenous on exogenous variables was predicted and tested. Following Cohen [89], $R^{2}$ values between 0.02 and 0.13 are weak, whereas values ranging between 0.13 to 0.26 are considered moderates, while values above 0.26 are substantial. Table 4 and Figure 2 stated that $R^{2}$ of exogenous variables ACAP, OLC, and IC were $24.1 \%, 15.3 \%$, and $60.7 \%$, respectively. Hence, the variance explained by the endogenous variable on ACAP, OLC and IC was moderate for ACAP and OLC and substantial for IC, suggesting it was the most reliable relationship with all dependent variables.

The study also tested the effect of control variables, namely the company age, based on years of operation, and their size (number of employees). Results show that firm size $(\beta=0.168, t=2.37, p>0.05)$ was statistically significant, indicating that these firms 
acquire considerable resources and investment power to advance technological innovation capabilities. Whereas the firm's age $(\beta=0.126, \mathrm{t}=1.654, p<0.10)$ was significant, years of operation were essential to acquire enough experience and knowledge to facilitate innovation capabilities.

\subsection{Testing Mediation Effect}

Using $[90,91]$ 's approach, the study examined the mediation effect of ACAP and OLC between entrepreneurship orientation (EO) and innovation capability (IC). The result tabulated in Table 5 shows that EO's indirect impact on IC has a beta value of 0.276 and a $\mathrm{t}$-value of 8.243, respectively. As recommended by [92], the variance accounted for (VAF) that determines the indirect effect size concerning the total effect was calculated. In this study, the VAF= direct effect/total effect has a value of $0.276 / 0.537=0.513$, indicating that $51.3 \%$ of the EO effect on IC is explained via the existence of the mediation effect of ACAP. Since the VAF is greater than $20 \%$ but less than $80 \%$, inferring that ACAP partially mediates this relationship, $\mathrm{H} 3$ is supported. The same goes for the mediation hypothesis (H7), where the VAF of the EO on IC has a value of $0.318 / 0.537=0.592$, indicating that OLC partially mediates the relationship between EO and IC. Thus, H7 is supported.

Table 5. Indirect effect results.

\begin{tabular}{|c|c|c|c|c|c|c|c|}
\hline \multirow{2}{*}{$\mathbf{H}$} & \multirow{2}{*}{ Relationship } & \multirow{2}{*}{ Std- B } & \multirow{2}{*}{$t$-Value } & \multirow{2}{*}{$p$-Value } & \multicolumn{2}{|c|}{ Confidence Interval } & \multirow{2}{*}{ Decision } \\
\hline & & & & & $2.50 \%$ & $97.50 \%$ & \\
\hline $\mathrm{H} 3$ & $\mathrm{EO} \rightarrow \mathrm{ACAP} \rightarrow \mathrm{IC}$ & 0.276 & 8.243 & $0.000 * *$ & 0.221 & 0.327 & Supported \\
\hline H7 & $\mathrm{EO}->\mathrm{OLC}->\mathrm{IC}$ & 0.318 & 5.886 & $0.001 * *$ & 0.034 & 0.106 & Supported \\
\hline \multicolumn{8}{|c|}{ Variance Accounted for (VAF) of the Mediator Variable for ACAP and OLC } \\
\hline IVs & Mediator & DV & $\begin{array}{c}\text { Indirect } \\
\text { effect }\end{array}$ & $\begin{array}{l}\text { Total } \\
\text { effect }\end{array}$ & VAF $(\%)$ & \multicolumn{2}{|c|}{ Type } \\
\hline $\mathrm{EO}$ & ACAP & $\mathrm{IC}$ & 0.276 & 0.537 & 51.3 & \multicolumn{2}{|c|}{ Partially } \\
\hline $\mathrm{EO}$ & CLO & $\mathrm{CI}$ & 0.318 & 0.537 & 59.2 & \multicolumn{2}{|c|}{ Partially } \\
\hline
\end{tabular}

Note IVs: independent variable, DV: dependent variable, EO: entrepreneurship orientation, ACAP: absorptive capacity, OLC: organizational learning capability, IC: innovation capability. ${ }^{*} p<0.001$ (1 tailed).

By applying PLS-SEM and through blindfolding procedures suggested by [93], the study predicts the model's relevance $\left(Q^{2}\right)$. Values greater than zero or near to 1 indicate that the research model is relevant, demonstrating interrelationships' power [86]. $Q^{2}$ Values presented in Table 6 show that absorptive capacity, organizational learning capability, and innovation capability were $0.217,0.148$, and 0.478 , respectively, all greater than zero, showing the strong connectedness among exogenous constructs estimating that the core issue of the study was empirically relevant.

Table 6. Results of the predictive relevance of the research model.

\begin{tabular}{cc}
\hline Variables & Predictive Relevance $Q^{2}$ \\
\hline Absorptive capacity (ACAP) & 0.217 \\
Organizational learning capability (OLC) & 0.148 \\
Innovation capability (IC) & 0.478 \\
\hline
\end{tabular}

\section{Discussion}

Following the dynamic capability view, this study tested and extended the RBV theory's body by developing an argument concerning EO, AC, and OLC's pivotal role in fostering innovation capabilities. Mainly for firms, (1) acquiring sophisticated AC aims to support innovation-building activities and thereby to respond to the call of Engelen, Kube [5] for further examination on the critical role of AC in the EO research stream, and (2) organizational learning acts as a primary source for creating knowledge and developing skills to improve innovation capabilities, hence responding to Alegre and Chiva's [15] call for more research on the association impact of OLC in the context of EO. Past studies [7,94] 
illustrated an insignificant association impact between EO and innovation. This study has the opposite findings. The findings show that the capability of innovation activities is highly reliant on EO.

Research streams on the association impact of EO-AC have been debated and studied from several perspectives and methodologies [5]. Most studies emphasized the relationship between EO-firm performance from different measures introducing various moderating and mediating factors. These studies have overlooked $\mathrm{AC}^{\prime}$ 's importance as either determinant or intermediary factors on EO-IC's relationship and their outcomes on organizational capabilities [5]. Thus, this study fills this gap by empirically testing the hypothesis and extending the body of entrepreneurship and dynamic capability literature. The first hypothesis $(\mathrm{H} 1)$ revealed that $\mathrm{EO}$ positively impacts $\mathrm{AC}$, confirming that $\mathrm{H} 1$ is supported. This means that those entrepreneurially oriented firms are more aware of the importance of empowering activities associated with AC during knowledge creation processes that need to be exploited for commercial ends [10,11]. This finding supports and provides further evidence for the DCT lens by assuming the need to achieve close interaction between EO-AC - thus confirming the first hypothesis, which is evident since EO attitudes are characterized by innovativeness, proactiveness and risk-taking [28]. Therefore, the process of knowledge creation tends to be embedded within EO behaviors. This could foster AC as the vital pillar of successful EO [5].

Past research on AC and its impact on organizational outcomes has been contradictory and missing. The findings of Lee, Leong [41] revealed an insignificant relationship between $\mathrm{AC}$ and technological innovation. In comparison, Aljanabi [40] confirms a positive impact of AC on the process and product innovation. These inconclusive results could increase the debate about the validity of DCT and its assumptions about AC as a dynamic capability to improve EO-firm performance, leading to a call for further examination. However, this study's findings indicated that $\mathrm{AC}$ has a significant and positive effect on innovation capability, thereby supporting $\mathrm{H} 2$. The reasons behind the estimation impact of AC on IC are the importance of possessing external knowledge sources through AC activities. This leads to reconfiguring existing knowledge and practices with newly acquired ones and recombining them to formulate new skills, know-how, and practices that needed to be applied for product and process innovation. Due to these advantages associated with $\mathrm{AC}$, it can be seen why firms rely on it to source and leverage external knowledge for commercial ends.

Following the theoretical assumptions of this research, the findings of the third hypothesis (H3) indicated that AC partially mediates the relationship between EO and IC. This suggesting that the firm's capacity to absorb and exploit external knowledge much more beneficial to support $\mathrm{EO}$, which in turn led to developing the capacity of innovation activities. However, our study contradicts the study findings [95]. This means that AC helps firms' EO to determine and exploit their business opportunities based on the capacity of innovation activities. Therefore, owning knowledge is an essential catalyst for pursuing successful EO. The findings also show the critical role of external knowledge and its impact in restructuring the internal knowledge base to fit the business changes. These capabilities are embedded within the organizational culture and appeared in the business processes and structure.

The study findings indicated that EO positively impacts innovation capabilities, hence H4 supported. This means that EO demonstrated strong attention to developing IC [15]. Firms that are entrepreneurially oriented viewed innovation as a key strategic solution for introducing new products and entering the markets with high risk-taking [55]. Since EO is a proactive risk-taking strategy seeking to exploit business opportunities, innovation is the foremost vital pillar that EO must stand on. This leads to developing firms capacities, joining the new venture and extending its market share. EO is a new promise that makes firms able to enhance their innovation capacities to deal with entrepreneurial opportunities. Studies have found that EO is one of the primary sources of innovation capabilities [5,40]. The results provide evidence on EO's importance in streaming and developing organizational capabilities as advocated by the DCT lens. 
For the fifth hypothesis, the study found that EO positively impacts OLC, inferring that $\mathrm{H} 5$ was supported. The study findings provide significant insight into the debate about EO's role in engaging and improving learning processes to increase the capacity to address business opportunities and support innovation capabilities. Therefore, entrepreneurially oriented firms believe that learning processes and acquiring relevant knowledge are essential in dealing with uncertainty by fostering and reconfiguring internal capabilities to fit external business changes. EO, therefore, covers the central theme of OLC to encounter and respond to the external environment.

The findings show that OLC possesses a significant positive impact on IC, hence H5 was supported. The results prove that OLC helps firms acquire and develop the existing knowledge base and practices, which pushes firms forward to build innovation capacities and served as an essential organizational catalyst [15]. OLC plays a significant role in advancing learning processes concerning businesses and practices, yielding unique valuable knowledge over time, thus improving and innovating new ideas, techniques, procedures and designs. These could dramatically lead to advancing new businesses, techno-innovation products, and a sense of business opportunities [38].

Results also provide indirect support for hypothesis H7. However, the mediating effect of OLC on the relationship between EO and innovation capabilities is found to be partial. There is a positive relationship between $\mathrm{EO}$ and OLC; there is a positive relationship between OLC and innovation capability. Finally, the direct effect of EO on innovation capability is significant. These results support H7 by illustrating a partial mediating role of OLC on the relationship between EO and innovation capability. This mediation relationship is also relevant in understanding the impact of $\mathrm{EO}$ on the innovation process and performance outcomes. This study's findings support past research and extend the EO-IC research stream [15].

This study demonstrates that AC and OLC can improve firms' strategic attitudes to reinforce $\mathrm{EO}$ practices and then advance innovation capabilities from a managerial perspective. AC and OLC provide insightful knowledge, know-how and skills to help EO by increasing the innovation of ideas and introducing innovative opportunities. This study is empirically-based research responding to several calls to elaborate and support dynamic capability theory to examine the interrelationships between constructs from another context and in dynamic environmental conditions. The study stands on past studies that investigated the relationships between research model variables. Yet, few attempts have been made to address the link between OLC and EO, which lacks understanding of how learning orientation promotes entrepreneurial opportunities. This study emphasizes these constructs as ambiguous, occurring in the literature for understanding the role of OLC and absorptive capacity concerning EO and innovation capacities, more particularly in the emerging economies where conditions and firms' capabilities differ and are under development. To conclude, this study tries to explain these issues by elaborating on how these capabilities are created, developed, and leveraged from the entrepreneurship and innovation perspective.

\section{Conclusions, Implications and Limitation of the Study}

This study emphasized the importance of absorptive capacity and organizational learning as beneficial and critical EO solutions to facilitate innovation capabilities [5,15]. The study consists of several points that might lead to support of EO and competitive advantages. The strategic and management entrepreneurship scholars have agreed that $\mathrm{EO}$ is one of the primary sources of exploring and transferring opportunities into commercial ends $[1,5]$. This can happen when EO strategies are based on reconfiguring existing dynamic capabilities to fit the observed and explored opportunities. Therefore, EO development has relied on IC. While dynamic capability and entrepreneurship researchers agree that EO is a vibrant and essential source for analyzing opportunities, innovation capabilities are the fundamental solution that bridges and accompanies EO to grasp it. 
Moreover, this study suggests that firm EO continuously keeps responding to the external environment by providing innovative products, which confer EO's potential role in developing important capabilities. This could improve the learning process and absorption capacities to deal with relevant knowledge and information associated with the emerging opportunities. Therefore, this research confirms that AC is a dynamic and critical capability developed to benefit from innovation activities stages. This study concluded that acquiring knowledge might be useless and not beneficial for firms. However, improving innovation activities highly depends on the absorptive capacity to turn and bridge the link between external and internal knowledge base into outcomes [42]. Therefore, the capability of innovation activities relies on absorptive capacity. Hence, the more the absorptive capacity is merged within EO activities, the more EO's increased IC impact. AC is the primary source that EO stands on with its four knowledge creation steps for commercial ends. Absorptive capacity enables the cognitive skills of EO in dealing with opportunities, either observed or unobserved.

This study also intends to discover EO's role in improving innovation capability through the support of organizational learning capability. EO is a proactive strategy that seeks to address business opportunities $[1,59]$ innovatively. This study argued that the firm's innovation capabilities are highly associated with OLC by integrating the new ideas, routines and skills into business processes and design, thus enhancing the entire business operation. This could also lead to enabling EO proactive behavior to seek external business opportunities. Therefore, OLC can be more effective as a driving force of IC. Besides, OLC and EO complement each other, which means that OLC possesses a strategic role in EO's lens [15]. In our study, we have found that OLC mediates the relationship between EO and innovation capability. Results suggest that OLC increases EO's impact on a firm's innovation capability by supporting an entrepreneur's knowledge and skills to upgrade, reconfigure, and advance business operation techniques.

Besides, OLC encourages and provides a clear image of business opportunities that EO must capture and exploit. This study suggests that the relationship between EO and innovation capability depends on organizational factors that facilitate organizational learning processes [15]. Organizational learning is considered a fundamental innovation source, as new ideas and practices are essential to developing new products and processes. This study contributes to the entrepreneurship literature by offering evidence of the crucial role of OLC in fostering EO goals, such as increasing firm innovation capability and performance. EO is not always able to influence the innovation capacity if OLC is ignored or not taken into consideration. OLC is a crucial factor that seeks to promote IC and EO. The literature also highlighted several points of view and inconclusive results about the relationship between EO and innovation capability, suggesting that intermediate links must be involved, such as organizational learning, to improve EO's impact on innovation outcomes.

The study frame is based on a dynamic capability perspective to enrich the entrepreneurship literature dealing with absorptive capacity and organizational learning as the central dynamic capabilities sources. This leads to promotion and support of EO activities and enhances their proactive strategies to observe opportunities and expand businesses. The study offers further evidence from emerging countries where government policies, stakeholders and firms are less experienced in emphasizing EO as an essential potential source to predict innovation capabilities and advance small businesses. Furthermore, this study used a DCT lens to explain and check the differences of EO and its outcomes on innovation activities between well-developed and emerging ones. It established literature from the EO emerging context compared to the developed context, where sources, conditions and cultures differ, making results and generalizable ideas and arguments about the importance of EO, ACAP, and OLC for innovation outcomes. Furthermore, the study extended the RBV lens, establishing the importance of organizational resources as a vital pillar for creating competitive advantages in emerging countries. 
This study suggests that policymakers should emphasize developing sources of knowledge (data) and its smooth access for all stakeholders much more. Policymakers should provide technological platforms and training workshops that facilitate innovation activities and empower EO cognitive skills. This study explains the need to develop entrepreneurial drivers such as knowledge creation and interpersonal skills created and developed by absorptive capacity and learning orientation, fostering entrepreneurial activities for innovation outcomes.

The study also consists of several restrictions and limitations. The study proposed some points that must be discussed in the subsequent analyses. So far, there has been a lack of empirical studies investigating EO and OLC's cumulative impact on innovation outcomes [16]. This could yield inconclusive results and perceptions on the nature of the relationship between $\mathrm{EO}$ and OLC within various contexts and cultures. Hence, future studies must focus on this study by incorporating other organizational and contextual factors between EO, OLC and innovation capability [15]. This study also applied a cross-sectional survey technique where the data have been collected at one point in time. Thus, it is suggested to use a longitudinal approach to capture the development of innovation and its outcomes across a specific period. Then we can confirm the importance of EO on innovation outcomes in the light of OLC. Furthermore, the study covers a specific geographic area (the Algerian context), and it is not certain whether it can be generalized for other neighboring countries such as Tunisia or not, as well as for other developing countries.

Author Contributions: Conceptualization L.M.; methodology, L.M., A.A.L. and A.A.S.; software, L.M. and F.B.; validation, L.M. and A.A.L.; formal analysis, L.M. and A.A.S.; investigation, L.M., A.A.S. and F.B.; data curation, L.M. and A.A.L.; writing-original draft preparation, L.M.; writingreview and editing, L.M., A.A.L. and F.B. All authors have read and agreed to the published version of the manuscript.

Funding: This research received no external funding.

Institutional Review Board Statement: Not applicable.

Informed Consent Statement: Not applicable.

Data Availability Statement: Not applicable.

Acknowledgments: The authors extend their appreciation to the Deanship of Scientific Research at King Khalid University for funding this work through research groups program under grant number (G.R.P.2 /176/42).

Conflicts of Interest: The authors declare no conflict of interest.

\section{References}

1. Hughes, M.; Morgan, R.E. Deconstructing the relationship between entrepreneurial orientation and business performance at the embryonic stage of firm growth. Ind. Mark. Manag. 2007, 36, 651-661. [CrossRef]

2. Patel, P.C.; Kohtamäki, M.; Parida, V.; Wincent, J. Entrepreneurial orientation-as-experimentation and firm performance: The enabling role of absorptive capacity. Strat. Manag. J. 2015, 36, 1739-1749. [CrossRef]

3. Krauss, S.I.; Frese, M.; Friedrich, C.; Unger, J.M. Entrepreneurial orientation: A psychological model of success among southern African small business owners. Eur. J. Work Organ. Psychol. 2005, 14, 315-344. [CrossRef]

4. Covin, G.J.; Slevin, D.P. A conceptual model of entrepreneurship as firm behavior. Entrep. Theory Pr. 1991, 16, 7-26. [CrossRef]

5. Engelen, A.; Kube, H.; Schmidt, S.; Flatten, T.C. Entrepreneurial orientation in turbulent environments: The moderating role of absorptive capacity. Res. Policy 2014, 43, 1353-1369. [CrossRef]

6. Boone, C.; Lokshin, B.; Guenter, H.; Belderbos, R. Top management team nationality diversity, corporate entrepreneurship, and innovation in multinational firms. Strat. Manag. J. 2019, 40, 277-302. [CrossRef]

7. Messersmith, G.J.; Wales, W.J. Entrepreneurial orientation and performance in young firms: The role of human resource management. Int. Small Bus. J. 2013, 31, 115-136. [CrossRef]

8. Meirun, T.; Makhloufi, L.; Hassan, M.G. Environmental Outcomes of Green Entrepreneurship Harmonization. Sustainability 2020, 12, 10615. [CrossRef]

9. Teece, J.D.; Pisano, G.; Shuen, A. Dynamic capabilities and strategic management. Strat. Manag. J. 1997, 18, 509-533. [CrossRef]

10. Zahra, A.S.; George, G. Absorptive capacity: A review, reconceptualization, and extension. Acad. Manag. Rev. 2002, 27, 185-203. [CrossRef] 
11. Cohen, M.W.; Levinthal, D.A. Absorptive capacity: A new perspective on learning and innovation. Adm. Sci. Q. 1990, 128-152. [CrossRef]

12. Zahra, A.S.; Sapienza, H.J.; Davidsson, P. Entrepreneurship and dynamic capabilities: A review, model and research agenda. J. Manag. Stud. 2006, 43, 917-955. [CrossRef]

13. Ferreira, J.; Coelho, A.; Moutinho, L. Dynamic capabilities, creativity and innovation capability and their impact on competitive advantage and firm performance: The moderating role of entrepreneurial orientation. Technovation 2020, 92, 102061. [CrossRef]

14. Sheng, L.M.; Chien, I. Rethinking organizational learning orientation on radical and incremental innovation in high-tech firms. J. Bus. Res. 2016, 69, 2302-2308. [CrossRef]

15. Alegre, J.; Chiva, R. Linking entrepreneurial orientation and firm performance: The role of organizational learning capability and innovation performance. J. Small Bus. Manag. 2013, 51, 491-507. [CrossRef]

16. Martín-de Castro, G.; López-Sáez, P.; Delgado-Verde, M.; Sanz-Valle, R.; Naranjo-Valencia, J.C.; Jiménez-Jiménez, D.; PerezCaballero, L. Linking organizational learning with technical innovation and organizational culture. J. Knowl. Manag. 2011, 15, 997-1015.

17. Thomas, J.; Graves, C. Internationalization of the family firm: The contribution of an entrepreneurial orientation. J. Bus. Entrep. 2005, 17, 91 .

18. Anderson, A.; Ronteau, S. Towards an entrepreneurial theory of practice; emerging ideas for emerging economies. J. Entrep. Emerg. Econ. 2017, 9, 110-120. [CrossRef]

19. Belousova, O.; Hattenberg, D.Y.; Gailly, B. Organizational Mindset of Entrepreneurship; Springer: Berlin/Heidelberg, Germany, 2020; pp. 211-233.

20. Jayawarna, D.; Jones, O.; Macpherson, A. Entrepreneurial potential: The role of human and cultural capitals. Int. Small Bus. J. 2014, 32, 918-943. [CrossRef]

21. Yeniaras, V.; Di Benedetto, A.; Kaya, I.; Dayan, M. Relational governance, organizational unlearning and learning: Implications for performance. J. Bus. Ind. Mark. 2020, 36, 469-492. [CrossRef]

22. Tian, H.; Dogbe, C.S.K.; Pomegbe, W.W.K.; Sarsah, S.A.; Otoo, C.O.A. Organizational learning ambidexterity and openness, as determinants of SMEs' innovation performance. Eur. J. Innov. Manag. 2020. [CrossRef]

23. Dess, G.G.; Dess, G.G.; Ireland, R.D.; Zahra, S.A.; Floyd, S.W.; Janney, J.J.; Lane, P.J. Emerging issues in corporate entrepreneurship. J. Manag. 2003, 29, 351-378.

24. Morgan, E.R.; Berthon, P. Market orientation, generative learning, innovation strategy and business performance interrelationships in bioscience firms. J. Manag. Stud. 2008, 45, 1329-1353. [CrossRef]

25. Arzubiaga, U.; Kotlar, J.; De Massis, A.; Maseda, A.; Iturralde, T. Entrepreneurial orientation and innovation in family SMEs: Unveiling the (actual) impact of the Board of Directors. J. Bus. Ventur. 2018, 33, 455-469. [CrossRef]

26. Ibarra-Cisneros, A.M.; Hernandez-Perlines, F. Entrepreneurial orientation, absorptive capacity and business performance in SMEs. Meas. Bus. Excel. 2019, 24, 417-429. [CrossRef]

27. Lumpkin, T.G.; Lichtenstein, B.B. The role of organizational learning in the opportunity-recognition process. Entrep. Theory Pr. 2005, 29, 451-472. [CrossRef]

28. Miller, D. Miller (1983) revisited: A reflection on EO research and some suggestions for the future. Entrep. Theory Pr. 2011, 35, 873-894. [CrossRef]

29. Covin, G.J.; Lumpkin, G.T. Entrepreneurial orientation theory and research: Reflections on a needed construct. Entrep. Theory Pr. 2011, 35, 855-872. [CrossRef]

30. Barreto, I. Dynamic capabilities: A review of past research and an agenda for the future. J. Manag. 2010, 36, 256-280. [CrossRef]

31. Anderson, R.A.; Gaddefors, J. Entrepreneurship and context: Is entrepreneurship research out of context? Dilemmas with (non) contextualised views of entrepreneurship. J. Asia Entrep. Sustain. 2017, 13, 3-9.

32. Miller, D.; Friesen, P.H. Innovation in conservative and entrepreneurial firms: Two models of strategic momentum. Strat. Manag. J. 1982, 3, 1-25. [CrossRef]

33. Covin, G.J.; Slevin, D.P. Strategic management of small firms in hostile and benign environments. Strat. Manag. J. 1989, 10, 75-87. [CrossRef]

34. Todorova, G.; Durisin, B. Absorptive capacity: Valuing a reconceptualization. Acad. Manag. Rev. 2007, 32, 774-786. [CrossRef]

35. Hernandez-Perlines, F. Moderating effect of absorptive capacity on the entrepreneurial orientation of international performance of family businesses. J. Fam. Bus. Manag. 2018, 8, 58-74. [CrossRef]

36. Hernández-Perlines, F.; Moreno-García, J.; Yáñez-Araque, B. Family firm performance: The influence of entrepreneurial orientation and absorptive capacity. Psychol. Mark. 2017, 34, 1057-1068. [CrossRef]

37. Rothaermel, T.F.; Alexandre, M.T. Ambidexterity in Technology Sourcing: The Moderating Role of Absorptive Capacity. Organ. Sci. 2009, 20, 759-780. [CrossRef]

38. Gebauer, H.; Worch, H.; Truffer, B. Absorptive capacity, learning processes and combinative capabilities as determinants of strategic innovation. Eur. Manag. J. 2012, 30, 57-73. [CrossRef]

39. Laforet, S. A framework of organisational innovation and outcomes in SMEs. Int. J. Entrep. Behav. Res. 2011, 17, 380-408. [CrossRef]

40. Aljanabi, A.R.A. The mediating role of absorptive capacity on the relationship between entrepreneurial orientation and technological innovation capabilities. Int. J. Entrep. Behav. Res. 2018, 24, 818-841. [CrossRef] 
41. Lee, V.-H.; Leong, L.-Y.; Hew, T.-S.; Ooi, K.-B. Knowledge management: A key determinant in advancing technological innovation? J. Knowl. Manag. 2013, 17, 848-872. [CrossRef]

42. Huang, K.S.; Wang, Y.-L. Entrepreneurial Orientation, Learning Orientation, and Innovation in Small and Medium Enterprises. In Proceedings of the 7th International Strategic Management Conference, Paris, France, 30 June-2 July 2011. [CrossRef]

43. Liao, H.S.; Wu, C. System perspective of knowledge management, organizational learning, and organizational innovation. Expert Syst. Appl. 2010, 37, 1096-1103. [CrossRef]

44. Hung, R.Y.-Y.; Lien, B.Y.-H.; Fang, S.-C.; McLean, G.N. Knowledge as a facilitator for enhancing innovation performance through total quality management. Total Qual. Manag. 2010, 21, 425-438. [CrossRef]

45. Lee, S.E.; Song, D.-W. The effect of shipping knowledge and absorptive capacity on organizational innovation and logistics value. Int. J. Logist. Manag. 2015, 26, 218-237. [CrossRef]

46. Medase, K.; Barasa, L. Absorptive capacity, marketing capabilities, and innovation commercialisation in Nigeria. Eur. J. Innov. Manag. 2019, 22, 790-820. [CrossRef]

47. Lumpkin, T.G.; Dess, G.G. Clarifying the entrepreneurial orientation construct and linking it to performance. Acad. Manag. Rev. 1996, 21, 135-172. [CrossRef]

48. Zhai, Y.-M.; Sun, W.-Q.; Tsai, S.-B.; Wang, Z.; Zhao, Y.; Chen, Q. An empirical study on entrepreneurial orientation, absorptive capacity, and SMEs' innovation performance: A sustainable perspective. Sustainability 2018, 10, 314. [CrossRef]

49. Zahra, S.A.; Filatotchev, I.; Wright, M. How do threshold firms sustain corporate entrepreneurship? The role of boards and absorptive capacity. J. Bus. Ventur. 2009, 24, 248-260. [CrossRef]

50. Hayton, C.J.; Zahra, S.A. Venture team human capital and absorptive capacity in high technology new ventures. Int. J. Technol. Manag. 2005, 31, 256-274. [CrossRef]

51. Zahra, A.S.; Hayton, J.C. The effect of international venturing on firm performance: The moderating influence of absorptive capacity. J. Bus. Ventur. 2008, 23, 195-220. [CrossRef]

52. Wales, W.J.; Gupta, V.K.; Mousa, F.-T. Empirical research on entrepreneurial orientation: An assessment and suggestions for future research. Int. Small Bus. J. 2013, 31, 357-383. [CrossRef]

53. Baker, E.W.; Sinkula, J.M. The complementary effects of market orientation and entrepreneurial orientation on profitability in small businesses. J. Small Bus. Manag. 2009, 47, 443-464. [CrossRef]

54. Aljanabi, A.A.R.; Noor, N.A.M. The mediating role of market orientation on entrepreneurial orientation, absorptive capacity and technological innovation capabilities. Asian Soc. Sci. 2015, 11, 219-234. [CrossRef]

55. Hong, J.; Song, T.H.; Yoo, S. Paths to success: How do market orientation and entrepreneurship orientation produce new product success? J. Prod. Innov. Manag. 2013, 30, 44-55. [CrossRef]

56. Ireland, D.R.; Hitt, M.A.; Sirmon, D.G. A model of strategic entrepreneurship: The construct and its dimensions. J. Manag. 2003, 29, 963-989.

57. Anderson, R.A.; Starnawska, M. Research practices in entrepreneurship: Problems of definition, description and meaning. Int. J. Entrep. Innov. 2008, 9, 221-230. [CrossRef]

58. Anderson, R.A.; Warren, L. The entrepreneur as hero and jester: Enacting the entrepreneurial discourse. Int. Small Bus. J. 2011, 29, 589-609. [CrossRef]

59. Otero-Neira, C.; Arias, M.J.F.; Lindman, M.T. Market orientation and entrepreneurial proclivity: Antecedents of innovation. Glob. Bus. Rev. 2013, 14, 385-395. [CrossRef]

60. Wang, C.L. Entrepreneurial orientation, learning orientation, and firm performance. Entrep. Theory Pr. 2008, 32, 635-657. [CrossRef]

61. Jayawarna, D.; Rouse, J.; Kitching, J. Entrepreneur motivations and life course. Int. Small Bus. J. 2013, 31, 34-56. [CrossRef]

62. Anderson, R.A.; Dodd, S.D.; Jack, S.L. Entrepreneurship as connecting: Some implications for theorising and practice. Manag. Decis. 2012, 50, 958-971. [CrossRef]

63. Keh, T.H.; Nguyen, T.T.M.; Ng, H.P. The effects of entrepreneurial orientation and marketing information on the performance of SMEs. J. Bus. Ventur. 2007, 22, 592-611. [CrossRef]

64. Sapienza, J.H.; de Clercq, D.; Sandberg, W.R. Antecedents of international and domestic learning effort. J. Bus. Ventur. 2005, 20, 437-457. [CrossRef]

65. Jiménez-Jiménez, D.; Sanz-Valle, R. Innovation, organizational learning, and performance. J. Bus. Res. 2011, 64, 408-417. [CrossRef]

66. Wheelwright, C.S.; Clark, K.B. Revolutionizing Product Development: Quantum Leaps in Speed, Efficiency, and Quality; Simon and Schuster: New York, NY, USA, 1992.

67. Hult, M.G.T.; Hurley, R.F.; Knight, A.G. Innovativeness: Its antecedents and impact on business performance. Ind. Mark. Manag. 2004, 33, 429-438. [CrossRef]

68. Argote, L.; McEvily, B.; Reagans, R. Managing Knowledge in organizations: An integrative framework and review of emerging themes. Manag. Sci. 2003, 49, 571-582. [CrossRef]

69. Lakhani, R.K.; Assaf, H.L.-; Tushman, M. Open innovation and organizational boundaries: Task decomposition, knowledge distribution and the locus of innovation. In Handbook of Economic Organization; Edward Elgar Publishing: Cheltenham, UK, 2013.

70. Albort-Morant, G.; Leal-Millán, A.; Cepeda-Carrión, G. The antecedents of green innovation performance: A model of learning and capabilities. J. Bus. Res. 2016, 69, 4912-4917. [CrossRef]

71. Olivera, F.; Argote, L. Organizational learning and new product development: CORE processes. In Shared Cognition in Organizations: The Management of Knowledge; Taylor \& Francis Group: Abingdon, UK, 1999; pp. 297-326. 
72. Wei, Z.; Yi, Y.; Guo, H. Organizational learning ambidexterity, strategic flexibility, and new product development. J. Prod. Innov. Manag. 2014, 31, 832-847. [CrossRef]

73. Love, E.P.; Irani, Z.; Edwards, D.J. Learning to reduce rework in projects: Analysis of firm's organizational learning and quality practices. Proj. Manag. J. 2003, 34, 13-25. [CrossRef]

74. Wong, P.S.; Cheung, S.O.; Yiu, R.L.; Hardie, M. The unlearning dimension of organizational learning in construction projects. Int. J. Proj. Manag. 2012, 30, 94-104. [CrossRef]

75. Keskin, H. Market orientation, learning orientation, and innovation capabilities in SMEs. Eur. J. Innov. Manag. 2006, 9, 396-417. [CrossRef]

76. Shaher, A.; Ali, K. The effect of entrepreneurial orientation on innovation performance: The mediation role of learning orientation on Kuwait SME. Manag. Sci. Lett. 2020, 10, 3811-3820. [CrossRef]

77. Altinay, L.; Madanoglu, M.; De Vita, G.; Arasli, H.; Ekinci, Y. The interface between organizational learning capability, entrepreneurial orientation, and SME growth. J. Small Bus. Manag. 2016, 54, 871-891. [CrossRef]

78. Alegre, J.; Chiva, R. Assessing the impact of organizational learning capability on product innovation performance: An empirical test. Technovation 2008, 28, 315-326. [CrossRef]

79. Pratono, A.H. Does firm performance increase with risk-taking behavior under information technological turbulence? J. Risk Financ. 2018, 19, 361-378. [CrossRef]

80. Krejcie, V.R.; Morgan, D.W. Determining sample size for research activities. Educ. Psychol. Meas. 1970, 30, 607-610. [CrossRef]

81. Kotrlik, J.; Higgins, C. Organizational research: Determining appropriate sample size in survey research appropriate sample size in survey research. Inf. Technol. Learn. Perform. J. 2001, 19, 43.

82. Henseler, J.; Ringle, C.M.; Sarstedt, M. A new criterion for assessing discriminant validity in variance-based structural equation modeling. J. Acad. Mark. Sci. 2015, 43, 115-135. [CrossRef]

83. Pallant, J. SPSS Survival Manual: A Step by Step Guide to Data Analysis Using SPSS; Allen \& Unwin: Sydney, Australia, 2011.

84. Kock, N. Common method bias in PLS-SEM: A full collinearity assessment approach. Int. J. E-Collab. 2015, 11, 1-10. [CrossRef]

85. Hair, J.F., Jr.; Sarstedt, M.; Hopkins, L.; Kuppelwieser, V. G Partial least squares structural equation modeling (PLS-SEM). Eur. Bus. Rev. 2014, 26, 106-121. [CrossRef]

86. Chin, W.W. The partial least squares approach to structural equation modeling. Mod. Methods Bus. Res. 1998, 295, 295-336.

87. Hair, J.F., Jr.; Sarstedt, M.; Ringle, C.M.; Gudergan, S.P. Advanced Issues in Partial Least Squares Structural Equation Modeling; SAGE Publications: New York, NY, USA, 2017.

88. Kline, E.; Wilson, C.; Ereshefsky, S.; Tsuji, T.; Schiffman, J.; Pitts, S.; Reeves, G. Convergent and discriminant validity of attenuated psychosis screening tools. Schizophr. Res. 2012, 134, 49-53. [CrossRef]

89. Cohen, J. Statistical Power Analysis for the Behavioral Sciences, 2nd ed.; Erbaum Press: Hillsdale, NJ, USA, 1988.

90. Preacher, J.K.; Hayes, A.F. Asymptotic and resampling strategies for assessing and comparing indirect effects in multiple mediator models. Behav. Res. Methods 2008, 40, 879-891. [CrossRef]

91. Preacher, J.K.; Hayes, A.F. SPSS and SAS procedures for estimating indirect effects in simple mediation models. Behav. Res. Methodsinstrum. Comput. 2004, 36, 717-731. [CrossRef]

92. Hair, F.J.; Ringle, C.M.; Sarstedt, M. Partial least squares structural equation modeling: Rigorous applications, better results and higher acceptance. Long Range Plan. 2013, 46, 1-12. [CrossRef]

93. Geisser, S. A new approach to the fundamental problem of applied statistics. Sankhyā Indian J. Stat. Ser. B 1975, $37,385-397$.

94. Ferraresi, A.A.; Quandt, C.O.; Dos Santos, S.A.; Frega, J.R. Knowledge management and strategic orientation: Leveraging innovativeness and performance. J. Knowl. Manag. 2012, 16, 688-701. [CrossRef]

95. Chang, S.; Gong, Y.; Way, S.A.; Jia, L. Flexibility-oriented HRM systems, absorptive capacity, and market responsiveness and firm innovativeness. J. Manag. 2013, 39, 1924-1951. [CrossRef] 